\title{
Capital Account Liberalization and Financial Stability: An Application of the Finite Distributed Lag Model
}

\author{
Joseph Stévy Mba Ollo ${ }^{1}$ \\ ${ }^{1}$ CIREGED, Omar Bongo University, Libreville, Gabon \\ Correspondence: Joseph Stévy Mba Ollo, CIREGED, Omar Bongo University, Libreville, Gabon. E-mail: \\ stevy.univ@gmail.com
}

Received: December 27, 2017

Accepted: January 24, $2018 \quad$ Online Published: January 30, 2018

doi:10.5539/ijef.v10n3p47

URL: https://doi.org/10.5539/ijef.v10n3p47

\begin{abstract}
The recurrence of financial crises in recent years has sparked renewed interest in the controversy over the implications of financial openness for the stability of the financial system. This article examines the relationship between capital account liberalization and financial stability in 31 sub-Saharan African countries for the period 1996-2015. Firstly, the study uses the Exchange Market Pressure Index (EMP) as the indicator of the degree of financial risk. Then, to determine the timing and the nature of the effect of capital account liberalization on financial stability, a finite distributed lag model is used. The estimation of long-term structural coefficients is obtained by the Fully Modified Ordinary Least Squares (FMOLS) method in panel data. The results show that liberalization of the capital account negatively affects financial stability after two years in sub-Saharan African countries. These results suggest that sub-Saharan African countries should standardize their strategies for liberalizing capital accounts and engage reforms to promote long-term capital flows that are more stable and improve the macroeconomic and institutional environment.
\end{abstract}

Keywords: capital account liberalization, financial stability, finite distributed lag model, panel data

\section{Introduction}

The international financial crisis of 2008 has revived the debate about the virtues of international capital liberalization (Eichengreen \& Rose, 2014), so that one wonders whether the opening of the capital account is not more a source of financial instability.

The theoretical literature on the link between capital account liberalization and financial stability is traditionally based on the idea that capital mobility lead to the development of the financial system (Caupin, 2014). This has two main raisons. First, access to foreign capital can increase the availability of funds to borrowers and then increase investment opportunities more than saving. Second, financial openness can reduce the problem of adverse selection and moral hazard by improving the financial infrastructure.

However, experiences in many developing countries reveal that these benefits are not systematic. The recent stream of financial crises and contagion after financial liberalization might some to suggest that the likelihood financial volatility and crises increase as a result of capital mobility (Daniel \& Jones, 2007; Kaminsky \& Reinhart, 1999). The positive or negative effects depend on the reliability of the institutional framework, the functioning of international financial markets (McKinnon \& Pill, 1997) and the level of penetration of foreign banks (Ho, 2016) and the exchange rate regime (Agenor, 2015).

In an empirical study, Reinhart and Reinhart (2008) include some Sub-Saharan African countries in the large sample of countries for examining the impact of capital inflow bonanzas on equity prices. They confirm the linkage between capital inflow bonanzas and financial crises. But, this study is not over all devoted to Sub-Saharan African countries.

To our knowledge, the issue of capital account liberalization effects on financial stability is still relatively unexplored empirically in Sub-Saharan Africa. However, this issue has a great interest for this region. Many countries are engaged in the process of financial openness, with different approaches and speeds (Murinde, 2009) to promote economic development. Moreover, they benefit from substantial growth in private capital flows since 2000 (Stiglitz \& Rashid, 2013) and the important presence of foreign bank, which can increase contagion risk.

This article is an empirical contribution to the study of the relationship between capital account liberalization and 
financial stability in sub-Saharan Africa. In particular, it highlights the lag time and the nature of the effect of capital account liberalization using an econometric application based on a finite distributed lag model with panel data. The rest of the work is organized as follows: Section 2 presents a brief literature review. Section 3 declines the methodology. Section 4 is devoted to analyzing the results. Finally, section 5 concludes.

\section{Literature Review}

The issue of capital account liberalization effects on financial stability has been the subject of a rich theoretical and empirical literature.

According the theoretical neoclassical model, capital shift from developed countries with resources abundance to developing countries with the return to capital is high. The capital flow into the developing countries relax the financial constrains, reduce the cost of capital and expand financing alternatives for both firms and households (Schmukler et al., 2003). Obstfeld (1995) and Kaminsky (2005) believe that capital mobility fosters stronger and more stable financial systems by improvement of capital access. But other literature believes that for many reasons such as countries characteristics, capital account liberalization leads financial instability (Daniel \& Jones, 2007).

Empirically, many studies highlight the positive or negative influence of financial liberalization on the stability of the financial system. In this respect, Demirgüç-Kunt and Detragiache (1998) suggest, based on a multivariate logit model and data covering the period 1980-1994 from developed and developing countries, that financial liberalization increases the likelihood of a banking crisis in Europe in presence of an unreliable institutional framework. But for Stiglitz (2000), the negative effect of the liberalization of the capital market on financial stability is systematic. This association is linked to the procyclical nature of international capital flows and exposure to external shocks. As a result, full financial liberalization is not desirable because diversification and contagion go together (Stiglitz, 2010).

For their part, Gourinchas and Obstfeld (2012) examine the financial crisis in the 20th century using a panel of developed and emerging countries for the period 1973-2010. According to these authors the accumulation of internal and external leverage in a content of explicit or implicit government guarantees to a liberalized financial sector is an important factor that triggers a crisis.

In a recent study, $\mathrm{Li}$ and $\mathrm{Su}$ (2016) analyze the effect of capital account openness on financial stability using microeconomic data covering 2330 banks from 75 countries between 1995 and 2013. The study concludes that liberalization of the capital account increases the risk of a banking crisis partly because of the strengthening of the market power and the concentrated sources of income of the national banks, which lead to imprudent behavior.

Many other studies investigate the link between capital account liberalization and financial stability focusing on composition of the capital flow, since short-term flows are considered more volatile than long-term ones (Bussière et al., 2016; Benmelech \& Dvir, 2013; Frankel \& Wei, 2004; Paliari \& Hannan, 2017; Milesi-Ferretti $\&$ Tille, 2011). In particular, these studies suggest that foreign direct investment (FDI) inflows are least volatile than portfolio debt investment which are driven by speculative considerations, and other investment flows. In this line, using a large panel for developed, emerging and developing economies during 1970-2003, Mauro (2007) suggests that FDI are remarkably stable comparatively to portfolio equity. The study of Sula and Willett (2009) confirms this result for 35 emerging economies during 1990-2003, notably as far as concern the reversibility of portfolio flows.

However, these are also studies that conclude that FDI is as volatile as other types of flows, and show no significant difference between short and long term flows. According to Göksu et al. (2015), the negative impact of FDI can be explained in developing economies by the high rates of unskilled workforce. Moreover, FDI can be assimilate to portfolio debt flows that can fluctuate in short-term, if the firms pass through a particular country for reducing their tax liabilities (Blanchard \& Acalin, 2016). Razin et al. (1999) in their study, show that FDI may have positive and negative impact.

Baum et al. (2017) investigate the link between components of gross capital flows and various financial stability indicators for 16 emerging and newly industrialized countries using quarterly panel data for the period 1989-2011. They show different types of capital flows are different effects on domestic financial stability. Moreover, this study concludes that the nature of implications for financial stability can depend of the direction of flow.

Another part of the empirical literature emphasizes the transitory or permanent nature of the effect of the liberalization of the capital account. In this regard, Angkinand et al. (2010), then Magud et al. (2012) argue that 
the negative effect of capital account openness on financial stability is felt only in the short term. Furceri et al. (2011), focusing on the dynamics of the domestic credit response to shocks in capital flows from developed and developing countries between 1970 and 2007, show that the capital flow shock increases the credit-to-GDP ratio over first two years, then this ratio declines in the long run. According to this result, there would be a transition period after which liberalization increases the probability of crisis. According to the authors, the extent and nature of the transitional effect depend on the exchange rate regime.

Finally, Shen and Yang (2015) study the lag time and the nature of the effect of capital account liberalization on financial stability in China between 1983 and 2013 from a finite distributed lag model. The results show that liberalization leads to instability in the financial system in the first year after liberalization, but in the long run the effect on financial stability becomes positive.

In all, the literature review shows that neither the theoretical works nor the empirical evidences have reached definite conclusions. The effect of financial openness on financial stability depends on the specific characteristics of each country, such as the institutional framework, the banking system and the structure of capital flows. Our study contributes empirically to this literature by analyzing the specific case of Sub-Saharan Africa economies. This study fills the gap in work on this very heterogeneous region. We explore whether capital account liberalization affects positively or negatively the financial stability and how long this effect lasts. For this purpose, we use a finite distributed lag model with panel data.

\section{Methodology and Data}

\subsection{Model Specification}

Like Shen and Yang (2015), we use a finite staggered delay model to test the effect of capital account liberalization on financial stability. Thus, we specify the following empirical equation:

$$
E M P_{i t}=\alpha+\varphi_{0} L B_{i t}+\varphi_{1} L B_{i, t-1}+\varphi_{2} L B_{i t-2}+\mu_{i t}
$$

Where:

- $\quad E M P_{i t}:$ The country-dependent variable $(i)$ in period $(t)$;

- $\quad L B_{i, t-j, j=0,1,2}$ : Independent variables;

- $\quad \alpha$ : The constant term;

- $\varphi_{j=0,1,2}$ : The parameters to be estimated;

- $\mu_{i t}=\zeta_{i}+\eta_{i t}$ : The component of the error term, with $\zeta_{i}$, the individual specific effect and the rest of the perturbation.

Two hypotheses are made on the individual specific effect:

- The model has a random effect if $\zeta_{i}$ is uncorrelated to the vectors of the explanatory variables;

- The model has a fixed effect if $\zeta_{i}$ is correlated to the vectors of the explanatory variables.

The dependent variable $E M P_{i t}$ is regressed on the current and delayed values of the variable $L B_{i t}$ and the constant term.

\subsection{Data}

To study the effect of capital account liberalization on financial stability in sub-Saharan Africa, panel data from 31 countries are used for the period 1996-2015. The length and number of countries depends on the availability of data. Variables and data sources are shown in Table 1 in the Appendix. The standard deviations and weights for each country are shown in Table 2 . The extreme (highest and lowest) values of the different times are shown in bold in Table 2 in the appendix.

In this study, the degree of financial risk is measured by the foreign exchange market pressure index (EMP) of Eichengreen et al. (1996), defined by the following equation:

$$
E M P_{i t}=\delta_{R E R} \frac{\Delta R E R_{i t}}{R E R_{i t}}+\delta_{R I R} \frac{\Delta R I R_{i t}}{R I R_{i t}}+\delta_{F E R} \frac{\Delta F E R_{i t}}{F E R_{i t}}
$$

Where:

$i$ and $t$ : indicate country and time respectively;

$R E R$ : the real exchange rate; 
$R I R$ : the real interest rate;

$F E R$ : the foreign exchange reserves;

$\delta_{R E R}, \delta_{R I R}, \delta_{R E R}$ : the weighting coefficients of each component.

The use of unweighted averages can be a simplistic approach. Given the volatility of foreign exchange reserves, exchange rates and interest rate differentials are quite different. Consequently, the various indices should be placed at the same level to prevent one of them dominating the others. The equality of the conditional variances of the three components of equation (2) is ensured by weighting according to the following equation:

$$
\delta_{i}=\left(\frac{1}{\sigma_{i}^{2}}\right) /\left(\frac{1}{\sigma_{R E R}^{2}}+\frac{1}{\sigma_{R I R}^{2}}+\frac{1}{\sigma_{F E R}^{2}}\right)
$$

with, $\sigma_{R E R}^{2}, \sigma_{R I R}^{2}$ and $\sigma_{F E R}^{2}$ the standard deviations of the real exchange rate, the real interest rate and the foreign exchange reserves respectively.

\section{Empirical Results}

The analysis of the stationarity of variables is carried out using three first-generation tests (Levin and Lin, 2002; Maddala and Wu, 1999; Im, Pesaran and Shin, 2003) and a second generation test (Pesaran, 2007) on panel data. Table 1 shows the various tests.

Table 1. Unit root test

\begin{tabular}{lcccc}
\hline \multicolumn{1}{c}{ Panel Unit Root test } & \multicolumn{2}{c}{ EMP } & LB \\
\hline & Level & Diff- $1^{\text {ere }}$ & Level & Diff- $1^{\text {ere }}$ \\
Maddala-Wu (1999) & $287.77^{* * *}$ & $410.92^{* * *}$ & $202.63^{* * * *}$ & $395.78^{* * * *}$ \\
Choi Z-stat (2002) & $-12.03^{* * *}$ & $-15.99^{* * *}$ & $-8.97 * * *$ & $-15.76^{* * *}$ \\
Im-Pesaran-Shin (2003) & $-16.04 * * *$ & $-22.55^{* * *}$ & $-9.83^{* * *}$ & $-21.63^{* * *}$ \\
CIPS (2007) & -2.36 & $-2.61^{* *}$ & $-2.64^{* *}$ & $-2.65^{* *}$ \\
\hline
\end{tabular}

Note. $(*),(* *)$ and $(* * *)$ indicate significance at $10 \%, 5 \%$ and $1 \%$, respectively.

The results of the various stationarity tests contained in Table 1 reveal that the variables examined are stationary. The Kao (1999) and Pedroni (1999) panel co-integration tests are used to check if the variables are cointegrated under the null non-cointegration hypothesis. Test results are shown in the following table.

Table 2. Cointegration test

\begin{tabular}{clcc}
\hline & & Statistic & p-value \\
\hline Kao (1999) & ADF t-stat & 4.20 & 0.00 \\
Pedroni (1999) & Panel v-statistic & -7.34 & 1.00 \\
& Panel rho-statistic & -6.81 & 0.00 \\
& Panel PP-statistic & -19.51 & 0.00 \\
& Panel ADF-statistic & -17.80 & 0.00 \\
& Group rho-statistic & -5.40 & 0.00 \\
& Group PP-statistic & -20.81 & 0.00 \\
& Group ADF-statistic & -17.82 & 0.00 \\
\hline
\end{tabular}

Note. Automatic lag length selection based on AIC with a max lag of 2.

Table 2 shows that in each case the test statistic rejects the null non-cointegration hypothesis. Six out of seven Pedroni tests accept the alternative hypothesis of a cointegrating relationship of the variables at the level of significance of $1 \%$. Therefore, the EMP and LB variables share a long-term relationship over the study period. In addition, the cointegration test of Westerlund (2007) is performed due to its good properties for small samples and its potency over traditional residue-based cointegration tests. The results are reported in the following table. 
Table 3. Westerlund cointegration test

\begin{tabular}{cccc}
\hline Statistique & Value & z-value & p-value \\
\hline $\mathrm{G}_{\mathrm{t}}$ & -5.75 & -23.52 & 0.00 \\
$\mathrm{G}_{\mathrm{a}}$ & -20.58 & -7.26 & 0.00 \\
$\mathrm{P}_{\mathrm{t}}$ & -29.24 & -20.36 & 0.00 \\
$\mathrm{P}_{\mathrm{a}}$ & -22.41 & -12.54 & 0.00 \\
\hline
\end{tabular}

Note. Average AIC selected lead and lag length is 2 .

The asymptotic p-value in Table 3 indicates that the Westerlund cointegration test confirms the results of the Pedroni and Kao tests at the $1 \%$ threshold. Table 4 below gives the results of the causality test of Dumitrescu and Hurlin (2012) which takes into account the heterogeneity between individuals.

Table 4. Causality dumitrescu-hurlin test

\begin{tabular}{lccc}
\hline Hypothèse nulle & Test & Statistics & p-value \\
\hline LB does not homogeneously cause EMP & $\bar{W}$ & 3.63 & \\
& $\bar{Z}$ & 4.53 & 0.00 \\
EMP does not homogeneously cause LB & $\tilde{Z}$ & 2.48 & 0.01 \\
& $\bar{W}$ & 1.82 & \\
& $\bar{Z}$ & -0.50 & 0.62 \\
\end{tabular}

The results in Table 4 indicate that LB causes EMP and the meaning of this causality is unidirectional. Interdependence between individuals is studied through the CD-test of Pesaran (2004) and Table 5 below provides the results of the test.

Table 5. Cross-sectional independence test Pesaran

\begin{tabular}{lccc}
\hline & CD test & p-value & Correlation in absolute value \\
\hline EMP & 2.63 & 0.009 & 0.19 \\
LB & 2.81 & 0.005 & 0.24 \\
\hline
\end{tabular}

Table 5 indicates that the statistic of the test CD rejects the null hypothesis of lack of interindividual dependence at least at $1 \%$. This means that the 31 countries of our panel are interdependent.

Based on the conclusions of the various previous tests, the estimation of the long-term coefficients is obtained by the Fully Modified Ordinary Least Squares (FMOLS) method. Unlike the biased OLS estimator, FMOLS has the advantage of addressing the problem of nonstationary regressors and the problem of simultaneity bias. According to Phillips and Hansen (1990), a semi-parametric correction can be made to the OLS estimator which eliminates the second order bias caused by the regressors being endogenous. Table 6 below presents the results of the FMOLS regression.

Table 6. Panel Fully Modified Least Squares (FMOLS)

\begin{tabular}{lcccc}
\hline & Coef. & Std. Error & t-stat & p-value \\
\hline LB & -0.29 & 0.07 & -4.25 & 0.00 \\
LB(-1) & -0.36 & 0.06 & -5.85 & 0.00 \\
LB(-2) & 0.59 & 0.05 & 11.22 & 0.00 \\
Observations & 558 & & & \\
Periods & 17 & & & \\
\hline
\end{tabular}

The model results in Table 6 show that liberalization of the capital account threatens financial stability in sub-Saharan Africa after a two-year period. Indeed, the coefficients indicate that the multiplier effect of the degree of liberalization of the capital account is negative during the first two years. This means that opening the capital account exerts no pressure on the foreign exchange market but contributes to short-term financial stability. This result can be explained by the gradualist liberalization approach adopted by several African countries and 
which favors less volatile FDI flows.

However, the long-term positive coefficient reflects the existence of financial pressures exerted on the foreign exchange market. This result shows that, in the long term, the liberalization of the capital account increases the risks for the financial market and results in the instability of the financial system.

\section{Conclusion}

Based on the estimation of a finite distributed lag model based on panel data, this study shows that capital account liberalization improves the financial stability of Sub-Saharan African countries during the first two years before increasing the risks of financial crisis. Indeed, it is necessary to wait until the third year so that the increase of the capital flows increases the pressure on the foreign exchange market, with the possibility of financial crisis.

\subsection{Implications of the Study}

It is therefore suggested that sub-Saharan African countries should standardize their strategies for liberalizing capital accounts. This strategy must be accompanied by reforms to promote long-term capital flows that are more stable and appropriate to a country's medium-term prospects. These reforms should also aim at improving the macroeconomic and institutional environment

\subsection{Research Limitations}

The main limitation of this study is that it does not explicitly consider specific country characteristics. The future research could be deepened in particular by taking into account the type of exchange rate regimes in force in each country, in order to better understand how they affect the link between capital account liberalization and financial stability.

\section{References}

Agénor, R. (2015). L'intégration financière internationale: Théories, évidences, et leçons des expériences récentes. OCP Policy Center, $\mathrm{n}^{\circ}$ 08/15

Angkinand, A. P., Sawangngoenyuang, W., \& Wihlborg, C. (2010). Financial liberalization and banking crises: A cross-country analysis. International Review of Finance, 10(2), 263-292. https://doi.org/10.1111/j.1468-2443.2010.01114.x

Baltagi, B. H., Demetriades, P. O., \& Law, S. H. (2009). Financial Development and Openness: Evidence from $\begin{array}{lllll}\text { Panel Data. Journal of Development Economics, } & \text { 89(2), } & \text { 285-96. }\end{array}$ https://doi.org/10.1016/j.jdeveco.2008.06.006

Baum, C. F., Pundit, M., \& Ramayandi, A. (2017). Capital Flows and Financial Stability in Emerging Economies. ADB Economics Working Paper Series, $\mathrm{n}^{\circ}$ 552/17. https://doi.org/10.22617/wps179090-2

Benmelech, E., \& Dvir, E. (2013). Does Short-Term Debt Increase Vulnerability to Crisis? Evidence from the East Asian Financial Crisis. Journal of International Economics, 89, 485-494. https://doi.org/10.1016/j.jinteco.2011.12.004

Blanchard, O., \& Acalin, J. ( 2016). What Does Measured FDI Actually Measure? Peterson Institute for International Economics. Technical Report $\mathrm{n}^{\circ}$ PB 16-17. Retrieved from https://piie.com/system/files/documents/pb16-17.pdf

Bussière, M., Schmidt, J., \& Valla, N. (2016). International financial flows in the new normal: Key patterns (and why we should care). EIB Working Papers, ${ }^{\circ} 02 / 16$

Caupin, V. (2014). L'économie mondiale 2015. Editions La Découverte, collection Repères, Paris.

Clarke, G., Cull R., Peria, M. S., \& Sánchez, S. (2005). Bank Lending to Small Businesses in Latin America: Does Bank Origin Matter?. Journal of Money, Credit, and Banking, 37, 83-118. https://doi.org/10.1353/mcb.2005.0003

Daniel, B. C., \& Jones, J. B. (2007). Financial Liberalization and Banking Crises in Emerging Economies. Journal of International Economics, 72(1), 202-221. https://doi.org/10.1016/j.jinteco.2006.07.009

Demirgüç-Kunt, A., \& Detragiache, E. (1998). The determinants of banking crises in developing and developed countries. Staff Papers, 45(1), 81-109. https://doi.org/10.2307/3867330

Eichengreen, B., \& Rose, A. (2014). Capital Controls in the 21st Century. Journal of International Money and Finance, 48, 1-16. https://doi.org/10.1016/j.jimonfin.2014.08.001 
Eichengreen, B., Rose, A. K., \& Wyplosz, C. (1996). Contagious currency crises. NBER Working Paper, ${ }^{\circ}$ 568/96. https://doi.org/10.3386/w5681

Frankel, J. A., \& Wei, S. J. (2004). Managing Macroeconomic Crises: Policy Lessons. NBER Working Paper Series $\mathrm{n}^{\circ}$ 10907/04. https://doi.org/10.3386/w10907

Furceri, D., Guichard, S., \& Rusticelli, E. (2011). The Effect of Episodes of Large Capital Inflows on Domestic

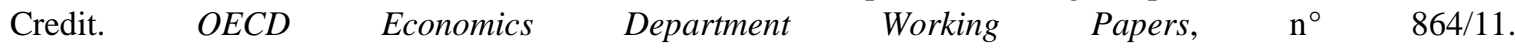
https://doi.org/10.1787/5kgc9kpv8vg8-en

Göksu, G., Kadıŏlu, E., \& Küçükkocaoğlu, G. (2015). Predicting Crises in Turkey Using an Exchange Market Pressure Model and Four-Way Decomposition Analysis of Gross Capital Flows. International Business Research, 8(11), 26-38. http://dx.doi.org/10.5539/ibr.v8n11p26

Gourinchas, P. O., \& Obstfeld, M. (2012). Stories of the twentieth century for the twenty-first. American Economic Journal: Macroeconomics, 4(1), 226-265. https://doi.org/10.1257/mac.4.1.226

Ho, S. Y. (2016). Global Economic and Financial Crisis: Exploring the Transmission Channels and Impacts on sub-Saharan African Economies. MPRA Paper, $\mathrm{n}^{\circ}$ 75658/16. https://doi.org/10.22495/rgcv6i4siart5

Kaminsky, G. L. (2005). International Capital Flows, Financial Stability and Growth. United Nations Department of Economics and Social Affairs (UN DESA) Working Paper, $\mathrm{n}^{\circ}$ 10/05. https://doi.org/10.18356/6f7080e3-en

Kaminsky, G. L., \& Reinhart, C. R. (1999). The Twin Crises: The Causes of Banking and Balance-of-Payments Problems. American Economic Review, 89(3), 473-500. https://doi.org/10.1257/aer.89.3.473

Kopp, E., Kaffenberger, L., \& Wilson, C. (2017). Cyber Risk, Market Failures, and Financial Stability. IMF Working Papers WP n ${ }^{\circ} 185 / 17$

Levchenko, A. A., \& Mauro, P. (2007). Do Some Forms of Financial Flows Help Protect Against "Sudden Stops"? World Bank Economic Review, 21(3), 389-411. https://doi.org/10.1093/wber/lhm014

Li, X., \& Su, D. (2016). Capital Account Liberalization and Bank Risk: Bank-level Evidences. Retrieved from https://editorialexpress.com/cgibin/conference/download.cgi?db_name=RESConf017\&pap_id=956

Madeley, J. (2003). Transnational corporations and developing countries: Big business, poor peoples. The ACP-EU Courier, 196, 36-38.

Magud, N. E., Reinhart, C. M., \& Vesperoni, C. M. (2012). Capital Inflows, Exchange Rate Flexibility, and Credit Booms. IMF Working Paper WP n ${ }^{\circ} 41 / 12$.

McKinnon, R. I., \& Pill, H. (1997). Credible Economic Liberalizations and Overborrowing. American Economic Review, 87(2), 189-193.

Milesi-Ferretti, G. M., \& Tille, C. (2011). The Great Retrenchment: International Capital Flows during the $\begin{array}{llll}\text { Global Financial } & \text { 289-346. }\end{array}$ https://doi.org/10.1111/j.1468-0327.2011.00263.x

Murinde, V. (2009). Capital Flows and Capital Account Liberalisation in the Post-Financial-Crisis Era: Challenges, Opportunities and Policy Responses. African Development Bank Group, WPS Working Paper $\mathrm{n}^{\circ}$ $99 / 09$.

Nier, E., Sedik, T. S., \& Mondino, T. (2014). Gross Private Capital Flows to Emerging Markets: Can the Global Financial Cycle Be Tamed?. IMF Working Paper WP $\mathrm{n}^{\circ}$ 196/14. https://doi.org/10.5089/9781498351867.001

Obstfeld, M. (1995). The logic of currency crises. Springer Berlin Heidelberg.

Pagliari, M. S., \& Hannan, S. A. (2017). The Volatility of Capital Flows in Emerging Markets: Measures and Determinants. IMF Working Paper $\mathrm{n}^{\circ}$ 41/17. https://doi.org/10.5089/9781475585254.001

Phillips, P. C. B., \& Sul, D. (2003). Dynamic panel estimation and homogeneity testing under cross section dependence. The Econometrics Journal, 6(1), 217-259. https://doi.org/10.1111/1368-423x.00108

Razin, A., Sadka, E., \& Yuen, C. W. (1999). Excessive FDI flows under asymmetric information. NBER Working Paper $\mathrm{n}^{\circ}$ 7400. https://doi.org/10.3386/w7400

Reinhart, C. M., \& Reinhart, V. (2008). Capital flow bonanzas: An encompassing view of the past and present. NBER Working Paper $\mathrm{n}^{\circ}$ 14321/08. https://doi.org/10.3386/w14321 
Schmukler, S. L., Zoido, P., \& Halac, M. (2003). Financial globalization, crises, and contagion. Paper of the background work for The Globalization World Bank Report. Retrieved from http://siteresources.worldbank.org/DEC/Resources/32459_Schmukler,_Zoido,_and_Halac_(Oct2003).pdf

Shen, Y., \& Yang, L. (2015). Does capital account liberalization affect the financial stability: Evidence from $\begin{array}{llll}\text { China. Journal of Reviews on Global Economics, 4, 152-158. } & \text {. }\end{array}$ https://doi.org/10.6000/1929-7092.2015.04.15

Stiglitz, J. E. (2000). Capital market liberalization, economic growth, and instability. World development, 28(6), 1075-1086. https://doi.org/10.1016/s0305-750x(00)00006-1

Stiglitz, J. E. (2010). Risk and global economic architecture: Why full financial integration may be undesirable. American Economic Review, 100(2), 388-392. . https://doi.org/10.1257/aer.100.2.388

Stiglitz, J. E., \& Rashid, H. (2013). Sub-Saharan Africa's Eurobond borrowing spree gathers pace. Why are an increasing number of developing countries resorting to expensive sovereign-bond issues? The Guardian, 26 June 2013. Retrieved from http://www.guardian.co.uk/business/economics-blog/2013/jun/26/subsaharan-africa-eurobond-borrowing-de bt

Sula, O., \& Willett, T. D. (2009). The Reversibility of Different Types of Capital Flows to Emerging Markets. Emerging Markets Review, 10(4), 296-310. https://doi.org/10.1016/j.ememar.2009.08.001

\section{Appendix}

\section{Table 1. Variables definitions}

\begin{tabular}{|c|c|c|}
\hline Variable & Proxy & Sources \\
\hline $\begin{array}{l}\text { Real exchange rate } \\
\text { (RER) }\end{array}$ & $\begin{array}{l}\text { Real effective exchange rate (CPI-based) (67 number of } \\
\text { trading partners considered) } \\
\text { (Real effective exchange rate (CPI basis) defined on the } 67 \\
\text { major trading partners) }\end{array}$ & $\begin{array}{l}\text { Darvas, Zsolt (2012a) 'Real effective exchange } \\
\text { rates for } 178 \text { countries: A new database', Working } \\
\text { Paper 2012/06, Bruegel, } 15 \text { March } 2012\end{array}$ \\
\hline $\begin{array}{l}\text { Real interest rate } \\
\text { (RIR)* }\end{array}$ & Real interest rate $(\%)$ & $\begin{array}{l}\text { World Bank: WDI and World Perspective (see } \\
\text { website). }\end{array}$ \\
\hline $\begin{array}{l}\text { Foreign exchange } \\
\text { reserves (FER) }\end{array}$ & Foreign exchange reserves (US\$ billion) & Islamic Development Bank - WDI \\
\hline Capital account (LB) & Ratio Capital account (Net, BoP, cur. US\$) /GDP (cur. US\$) & AFDB Socio-economic-database \\
\hline
\end{tabular}

Table 2. Descriptive Statistics

\begin{tabular}{|c|c|c|c|c|c|c|c|c|c|c|c|c|c|c|c|}
\hline \multirow[b]{2}{*}{ Pays } & \multirow[b]{2}{*}{ Obs } & \multicolumn{5}{|c|}{ EMP } & \multicolumn{3}{|c|}{ LB } & \multicolumn{2}{|c|}{ RER } & \multicolumn{2}{|c|}{ RIR } & \multicolumn{2}{|c|}{ FER } \\
\hline & & Moy. & $\begin{array}{l}\text { Std. } \\
\text { Dev. }\end{array}$ & Min & Max & Моy. & $\begin{array}{l}\text { Std. } \\
\text { Dev. }\end{array}$ & Min & $\operatorname{Max}$ & $\begin{array}{l}\text { Std. } \\
\text { Dev. }\end{array}$ & Weight & $\begin{array}{l}\text { Std. } \\
\text { Dev. }\end{array}$ & Weight & $\begin{array}{l}\text { Std. } \\
\text { Dev. }\end{array}$ & Weight \\
\hline & 20 & & 1.867 & & & & & & & & & & & 12.372 & 96 \\
\hline Botswana & 20 & 0.194 & 03 & -1.12 & & 01 & 002 & -0.001 & 07 & 6.739 & & 5.482 & & .404 & 683 \\
\hline Burundi & 20 & -0.012 & 697 & -1.373 & 2.359 & 0.091 & 150 & 0.007 & .704 & 23.090 & & 7.309 & & 0.115 & \\
\hline & 20 & & & -0.426 & & & & & & & & & & .520 & 600 \\
\hline Cape $\mathbf{V}$ & 20 & 0.297 & 0.874 & -0.525 & 3.778 & 0.019 & 0.010 & 0.003 & 0.038 & 3.786 & & 4.950 & 0.034 & 0.182 & 0.922 \\
\hline Chad & 20 & .132 & .476 & -0.631 & 1.573 & 0.025 & 0.014 & 0.009 & 0.055 & 7.388 & & 12.574 & 0.032 & 0.434 & 0.915 \\
\hline & 20 & & & & & & & & & & & & & & \\
\hline Cong & 20 & 2.093 & 7.415 & -0.767 & 33.202 & 0.029 & 0.061 & 0.001 & 0.217 & 8.258 & 194 & 20.205 & 0.079 & 2.210 & 0.726 \\
\hline Djibouti & 20 & 0.196 & 0.540 & -0.132 & 2.330 & 0.031 & 0.022 & -0.012 & 0.077 & 9.825 & 0.011 & 2.239 & 0.048 & 0.113 & 0.942 \\
\hline & 20 & & & & & & & & & & & & & & 0.904 \\
\hline & 20 & & & & & & & & & 4.144 & & 15.854 & & 0.995 & 0.768 \\
\hline & 20 & 0.033 & 0.286 & -0.438 & 0.912 & 0.058 & 0.103 & 0.000 & 0.485 & 39.396 & & 5.134 & 0.010 & 0.053 & 0.988 \\
\hline & 20 & & & & & & & & & & & & & & \\
\hline & 20 & & & -0.287 & & & 0.033 & 0.003 & & 21.487 & & 7.610 & & 0.058 & 0.990 \\
\hline Kenya & 20 & 0.023 & 0.352 & -0.762 & 0.754 & 0.007 & 0.003 & 0.002 & 0.015 & 16.505 & 0.100 & 7.943 & 0.207 & 2.376 & 0.693 \\
\hline
\end{tabular}




\begin{tabular}{lccccccccccccccc}
\hline Lesotho & 20 & 0.106 & 0.234 & -0.174 & 0.739 & 0.035 & 0.024 & 0.001 & 0.072 & 13.318 & 0.019 & 4.253 & 0.061 & 0.281 & 0.920 \\
Madagascar & 20 & 0.139 & 0.302 & -0.377 & 1.095 & 0.067 & 0.122 & 0.001 & 0.476 & 12.899 & 0.024 & 15.315 & 0.020 & 0.319 & 0.956 \\
Malawi & 20 & 0.171 & 0.463 & -0.376 & 1.037 & 0.035 & 0.144 & -0.003 & 0.647 & 30.319 & 0.005 & 12.767 & 0.011 & 0.149 & 0.984 \\
Mauritania & 20 & 0.277 & 0.630 & -0.718 & 1.737 & 0.026 & 0.070 & 0.000 & 0.282 & 8.710 & 0.031 & 6.492 & 0.042 & 0.294 & 0.927 \\
Mauritius & 20 & 0.071 & 0.170 & -0.164 & $\mathbf{0 . 3 5 4}$ & 0.000 & $\mathbf{0 . 0 0 0}$ & -0.001 & $\mathbf{0 . 0 0 0}$ & 7.594 & 0.097 & 4.007 & 0.184 & 1.024 & 0.719 \\
Mozambique & 20 & 0.122 & 0.189 & -0.182 & 0.570 & 0.082 & 0.079 & 0.022 & 0.291 & 9.067 & 0.072 & 3.103 & 0.209 & 0.902 & 0.719 \\
Namibia & 20 & 0.128 & 0.437 & -0.866 & 1.074 & 0.013 & 0.006 & 0.007 & 0.029 & 8.745 & 0.063 & 4.554 & 0.121 & 0.677 & 0.816 \\
Nigeria & 20 & $\mathbf{- 0 . 9 8 3}$ & 3.358 & $\mathbf{- 1 4 . 7 5 3}$ & 2.059 & 0.003 & 0.015 & -0.025 & 0.044 & $\mathbf{6 3 . 3 8 0}$ & 0.115 & 15.730 & 0.462 & $\mathbf{1 7 . 1 6 4}$ & 0.423 \\
Rwanda & 20 & 0.193 & 0.308 & -0.172 & 1.318 & 0.058 & 0.093 & 0.022 & 0.450 & 15.427 & 0.021 & 7.331 & 0.045 & 0.354 & 0.934 \\
Seychelles & 20 & 0.284 & 0.585 & -0.644 & 1.928 & 0.032 & 0.063 & 0.000 & 0.284 & 23.230 & 0.007 & 9.055 & 0.018 & 0.166 & 0.975 \\
Sierra Leone & 20 & 0.341 & 0.686 & -0.252 & 2.952 & 0.045 & 0.049 & 0.001 & 0.222 & 19.185 & 0.011 & 11.559 & 0.018 & 0.208 & 0.972 \\
South Africa & 20 & 0.085 & 0.367 & -0.342 & 1.266 & $\mathbf{0 . 0 0 0}$ & $\mathbf{0 . 0 0 0}$ & -0.001 & $\mathbf{0 . 0 0 0}$ & 11.151 & $\mathbf{0 . 1 9 5}$ & 3.232 & $\mathbf{0 . 6 7 4}$ & 16.657 & $\mathbf{0 . 1 3 1}$ \\
Swaziland & 20 & 0.131 & 0.386 & -0.279 & 1.200 & 0.003 & 0.007 & -0.009 & 0.023 & 6.827 & 0.031 & 4.522 & 0.047 & 0.231 & 0.922 \\
Tanzania & 20 & -0.172 & 0.662 & -2.495 & 0.486 & 0.040 & 0.037 & 0.012 & 0.147 & 20.369 & 0.053 & 5.797 & 0.185 & 1.410 & 0.762 \\
Uganda & 20 & 0.097 & $\mathbf{0 . 1 6 8}$ & -0.270 & 0.369 & 0.035 & 0.072 & -0.011 & 0.334 & 11.629 & 0.074 & 10.282 & 0.084 & 1.027 & 0.842 \\
Zambia & 20 & 0.108 & 1.353 & -4.264 & 3.509 & 0.042 & 0.057 & 0.000 & 0.204 & 22.888 & 0.040 & 6.728 & 0.137 & 1.123 & 0.822 \\
Panel & 620 & 0.220 & 2.028 & -14.753 & 33.202 & 0.031 & 0.073 & -0.025 & 0.704 & & & & & \\
\hline
\end{tabular}

Note. les nombres en gras indiquent les valeurs extrêmes dans chaque colonne.

\section{Copyrights}

Copyright for this article is retained by the author(s), with first publication rights granted to the journal.

This is an open-access article distributed under the terms and conditions of the Creative Commons Attribution license (http://creativecommons.org/licenses/by/4.0/). 